\title{
Microbial community diversity in the soil of Barrientos Island estimated by RAPD and Biolog Ecoplate methods
}

\author{
Learn-Han Lee ${ }^{1}$, Vengadesh Letchumanan ${ }^{1}$, Nurul-Syakima Ab Mutalib², Yoke Kqueen Cheah $^{3 *}$ \\ ${ }^{1}$ Novel Bacteria and Drug Discovery (NBDD) Research Group, Microbiome and Bioresource Research Strength (MBRS), \\ Jeffrey Cheah School of Medicine and Health Sciences, Monash University Malaysia, 47500, Selangor Darul Ehsan, Ma- \\ laysia \\ ${ }^{2}$ UKM Medical Molecular Biology Institute (UMBI), UKM Medical Centre, University Kebangsaan Malaysia, Kuala Lum- \\ pur, Malaysia \\ ${ }^{3}$ Department of Biomedical Sciences, Faculty of Medicine and Health Sciences, Universiti Putra Malaysia, Serdang 43300, \\ Malaysia
}

\begin{abstract}
The diversity of soil microbial communities at Barrientos Island with different soil characteristics were evaluated using PCR-based method random amplified polymorphic DNA (RAPD) and community level physiological profiles (CLPP) of Biolog Ecoplate. The soils were selected from 17 different locations around Barrientos Island inhabited by different breeders. Shannon-Weaver index and multivariate analysis were performed to characterize variations of soil microbial communities. Both RAPD and CLPP methods exhibited that most soils with different type of rookery and characteristics could possibly affect the DNA sequence diversity and soil microbial diversity. The abandoned type of rookery had the highest Shannon-Weaver index as exhibited by soil sample 445 (3.4 for RAPD) and 450 (3.09 for CLPP). Higher coefficients of DNA sequence similarity were found in soil samples colonized by similar breeders, like soil 442 and 446 (both were active Chinstrap rookery) shared highest similarity in DNA sequences (73.53). The cluster analysis of RAPD profiles by UPGMA and principle component analysis (PCA) of Biolog Ecoplate exhibited similar influence of type of rookery and soil condition towards soil microbial community diversity. The results may suggest that the change in microbial community DNA composition is accompanied with the change in microbial functional properties.
\end{abstract}

Keywords: Microbial; diversity; random amplified polymorphic DNA (RAPD); Biolog; soil; Barrientos Island

Received: 9th November 2019

Accepted: $10^{\text {th }}$ December 2019

Published Online: 18th January 2020
*Correspondence: Yoke Kqueen Cheah, Department of Biomedical Sciences, Faculty of Medicine and Health Sciences, Universiti Putra Malaysia, Serdang 43300, Malaysia. Email: ykcheah@upm.edu.my

Citation: Lee L-H, Letchumanan V, Ab Mutalib N-S, Cheah Y-K. Microbial Community Diversity in the Soil of Barrientos Island Estimated by RAPD and Biolog Ecoplate Methods. Prog Microbes Mol Biol 2020; 2(1): a0000046. https:// doi.org/10.36877/ pmmb.a0000046

\section{Introduction}

The soil microbial community is the most important composition of the soil ecosystem ${ }^{[1]}$. They are involved in many ecosystem processes such as nutrient transformation, litter decomposition, plant health maintenance and soil organic matter formation ${ }^{[2]}$. Soil microbiological parameters, such as microbial biomass carbon and basal respiration have been suggested and used as possible indicators of soil quality ${ }^{[3-5]}$.

Recently, soil microbial community structure is frequently used as indicators for soil quality and fertility ${ }^{[1]}$. However, the use of cultivation-based method to study soil microbial community are proven to be challenging as only a small fraction of microorganisms (less than $10 \%$ ) are culturable ${ }^{[6,7]}$. The limitation of culturable methods resulted in difficulty to understand the shift in the complex microbial community of soils ${ }^{[8]}$. These limitations could be overcome by using Biolog system and various molecular methods such as RAPD, PCR-DGGE, RFLP and others ${ }^{[1,9-14]}$. The advancement of molecular methods has enabled various advancement and discovery in the study of microbial genomics ${ }^{[15-28]}$.

The RAPD analysis uses arbitrary short primers that amplify the intervening portion of the genome, and creating variably sized amplicons ${ }^{[29]}$ that could be applied to study soil microbial community structure ${ }^{[9]}$ and bacteria genome $^{[30,31]}$. RAPD has become a popular DNA-based method as it is rapid, simple and able to provide meaningful information about soil microbial community than isolate-based methods ${ }^{[32]}$. The Biolog system is used to assess community level physiological profiles (CLPP) of a soil sample. It is a means of investigating the functional diversity of soils as they could reflect how the soil microbial communities could utilize a range of carbon substrates $^{[33]}$. In this study, RAPD and Biolog Ecoplate 
methods were used to investigate the influence of soil characteristics like type of rookery on soil microbial community diversity.

\section{Material and Methods}

\section{Environmental Sampling}

In 2007, during the XI Ecuadorian Antarctic Expedition to the Research Station "Pedro Vicente Maldonado", Greenwich Island, South Shetland Islands, sampling for analysis of microbial communities from the soil was carried out at Barrientos Island (coordinates: S $62^{\circ} 24^{\prime}$ $18.7^{\prime \prime}$ to S $62^{\circ} 24^{\prime} 32.4^{\prime \prime}$ and W $59^{\circ} 44^{\prime} 13.2^{\prime \prime}$ to W $59^{\circ}$ $45^{\prime} 39.3$ "). Top soil samples of upper $20 \mathrm{~cm}$ layer (after removing the top $2-3 \mathrm{~cm}$ ) were collected from 17 different sites within Barrientos Island. These sites have various interesting fauna and flora activities (Table 1). Soils were sampled into sterile plastic bags using an aseptic metal trowel, and kept in the dark for transport to Malaysia. Soils were subsequently stored at $-20^{\circ} \mathrm{C}$, with an aliquot stored at $-80^{\circ} \mathrm{C}$ for molecular analysis like RAPD. While a portion of each soil sample was stored in $4^{\circ} \mathrm{C}$ and analyzed by Biolog Ecoplate assay.

Table 1: Soil samples characteristics.

\begin{tabular}{|l|l|l|}
\hline $\begin{array}{l}\text { Soil } \\
\text { refer- } \\
\text { ence }\end{array}$ & Type of rookery / nest & Soil condition \\
\hline 442 & Active Chinstrap penguin & Guano \\
\hline 443 & Abandoned Gentoo penguin & Guano \\
\hline 444 & Abandoned Gentoo penguin & No guano \\
\hline 445 & Abandoned Gentoo penguin & No guano \\
\hline 446 & Active Chinstrap penguin & Guano \\
\hline 447 & Active Chinstrap penguin & No guano \\
\hline 448 & Active penguin & No guano \\
\hline 449 & Active Chinstrap penguin & Guano \\
\hline 450 & Abandoned Penguin & Guano \\
\hline 451 & $\begin{array}{l}\text { Active Gentoo penguin } \\
\text { (resting-deleted) area }\end{array}$ & Guano \\
\hline 452 & Abandoned Penguin & Guano \\
\hline 453 & Penguin resting area & Guano \\
\hline 455 & Active Gentoo penguin & Guano \\
\hline 456 & Abandoned Penguin & No guano \\
\hline 457 & Active Gentoo penguin & No guano \\
\hline 458 & $\begin{array}{l}\text { Seal colony } \\
\text { Giant Petrel nest }\end{array}$ & $\begin{array}{l}\text { Guano } \\
\text { No guano }\end{array}$ \\
\hline 460 & & \\
\hline
\end{tabular}

\section{Soil DNA Extraction and Purification}

To minimize possible contaminants, all post-sampling manipulations were performed in a UV-sterilized laminar box hood, using sterile glass vials. Total soil DNA was extracted and purified from $1 \mathrm{~g}$ dry weight of soil using GF-1 Soil Sample Extraction kit (Vivantis, Selangor, Malaysia). The kit uses a specially-treated silica-based material fixed into a column to efficiently bind DNA in the presence of high salt. This kit applies the principle of a mini-column spin technology and the use of optimized buffers to ensure that only DNA is isolated while cellular protein, humic acid and other low molecular weight impurities are removed during the subsequent washing stages. (Cat. No: GF-SD-025). DNA yield and quality were assessed by $0.8 \%(\mathrm{w} / \mathrm{v})$ agarose gel electrophoresis following by DNA quantification using a Biophotometer (Eppendorf, Hamburg, Germany) and ratio $\mathrm{A}_{260} / \mathrm{A}_{280}$ was measured. Pure DNA has an $\mathrm{A}_{260} / \mathrm{A}_{280}$ ratio of 1.7-1.9.

\section{PCR Amplifications and Fragment Visualization}

RAPD arbitrary primer OPO 05 (5'-CCCAGTCACT-3'), OPO 06 (5'-CCACGGGAAG-3') and OPO 18 (5'-CTCGCTATCC-3') was used for amplification of soil DNA by PCR using the Eppendorf Mastercycler (Eppendorf, Hamburg, Germany). The PCR reaction mixture consisted of $\sim 10 \mathrm{ng}$ of soil bacteria DNA, $2.0 \mu \mathrm{l}$ of 10X optimized PCR buffer with $20 \mathrm{mM} \mathrm{MgCl}, 2.0 \mu \mathrm{l}$ of $10 \mathrm{mM}$ dNTPs, 1 unit of Taq polymerase (Intron Biotechnology, South Korea) and $0.5 \mu \mathrm{l}$ of $100 \mathrm{nM}$ primer and sterile ultrapure water was added to final volume of $20 \mu \mathrm{l}$. The cycling parameters were $4 \mathrm{~min}$ at $94^{\circ} \mathrm{C}$ for pre-denaturation, 45 cycles each of $1 \mathrm{~min}$ at $94^{\circ} \mathrm{C}$ for denaturation, $1 \mathrm{~min}$ at $36^{\circ} \mathrm{C}$ for annealing, $1 \mathrm{~min}$ at $72^{\circ} \mathrm{C}$ for extension and $7 \mathrm{~min}$ at $72^{\circ} \mathrm{C}$ for final extension. The PCR amplification products were resolved by electrophoresis in $1.5 \%$ agarose gel (Promega, Madison, WI.), which was stained with ethidium bromide $\left(0.5 \mu \mathrm{g} \mathrm{ml}^{-1}\right)$ and viewed under a gel documentation system (Alpha Imager, Alpha Innotech, California).

\section{Data Analysis of RAPD Fingerprints}

Three arbitrary primers were used to amplify microbial community DNA from 17 soil samples. Since primer sequences were random and non-selective to soil DNA samples, amplification for one primer was equal to one random sampling from the whole microbial DNA sequences $^{[32]}$. The number of RAPD fragments was considered to represent the RAPD fragment richness $(S)$ of the whole DNA sequences. The calculations above rely on an assumption that each RAPD fragment contributes equally to the microbial diversity ${ }^{[32]}$.

Since RAPD fragments amplified in all 17 soil samples contributed to the diversity of DNA sequences differently as compared to those fragments amplified in only one, two, and three samples, it was necessary to make a modification for another diversity calculation. A fragment amplified in all 17 soil samples had the smallest contribution to the diversity because of no polymorphism, and therefore scored 0 for the diversity. A fragment amplified in only one sample had the biggest contribution and scored 1 . The other fragments, amplified in two or three samples, counted $2 / 3$ or $1 / 3$, respectively. This modification (modified richness, i.e., modified S), in fact, enlarged the contribution of the characteristic sequence to the DNA sequence diversity. The richness and modified richness of soil microbial community DNA sequences reflect to cer- 
tain extent the diversity of soil microbial community DNA sequences, but do not indicate the relative abundance of soil microbial community DNA sequences. Shannon-Weaver index is developed to measure the species diversity of the community by integrating species richness and abundance. Her, we used Shannon-Weaver index as a measure of soil microbial community DNA sequence diversity by molecular marker. Diversity of soil microbial community DNA sequences was estimated using the equation below:

$$
D \text { sh }=-\sum_{I=1}^{\mathrm{S}} P i \ln P i=-\sum_{I=1}^{\mathrm{S}}(\mathrm{Ni} / N) \ln (N i / N)
$$

where $D$ sh is Shannon-Weaver index, $P i$ is the percent of the $i$ th RAPD fragment gray degree to each DNA sample, $N i$ is the net gray degree quantity (subtracted by the background gray degree of a gel) of the $i$ th RAPD fragment in each DNA sample, $N$ is the total net gray degree quantity of all RAPD fragments examined in each DNA sample, and $\mathrm{S}$ is the number of RAPD fragments in each DNA sample. The range of $D$ sh is between 0 and $\ln (\mathrm{S})$. By merging the data of RAPD fragment net gray degrees from each primer into a single dataset, a cumulative diversity of ShannonWeaver index was calculated for each sample using the same equation above.

\section{RAPD-based Cluster Analysis}

By using BioNumerics version 6.0 gel analysis software (Applied Maths, Kortrijk, Belgium), the position of the markers in RAPD gels were normalized from lane-tolane and gel-to-gel variation. This normalization enables comparison of banding patterns originating from different RAPD gels, provided there was a high degree of gel reproducibility based on migration of standards. Then a binary matrix was constructed for each microbial community based on the presence and absence of bands. Jaccard's coefficient (a similarity measurement) was used to calculate the matrix and the data were subjected to clustering based on the unweighted pair group method using arithmetic averages (UPGMA) to identify samples that generated patterns similar to each other ${ }^{[34]}$. Results were displayed in dendrogram form to illustrate the relationship between microbial communities from different soil.

\section{Biolog EcoPlate Inoculation and Incubation}

One hundred and fifty $\mathrm{ml}$ of sediment slurry from each sample was placed in sterile $400 \mathrm{ml}$ beakers. Physiological saline solution was added to bring the volume to 200 $\mathrm{ml}$. The resultant slurry was sonicated in a water bath for $5 \mathrm{~min}$ before $15 \mathrm{ml}$ of the supernatant was extracted and centrifuged at $500 \mathrm{~g}$ for $3 \mathrm{~min}$. A $150 \mathrm{ml}$ aliquot of the centrifuged supernatant was then used to inoculate a microtitre Biolog EcoPlate. Biolog EcoPlates have 96 wells that contain 31 unique carbon compounds, in addition a control of distilled water repeated in triplicate. When bacteria use one of these carbon sources, tetrazolium dye is reduced by bacterial respiration and accumulates as insoluble formazin. These results in the well turning from clear to darker shades of purple depending on the amount of formazin produced ${ }^{[35]}$. Each plate was cultivated at $25^{\circ} \mathrm{C}$ for $168 \mathrm{~h}$, and the optical density at both $590 \mathrm{~nm}$ (color development plus turbidity) and 750 $\mathrm{nm}$ (turbidity only) was read every $24 \mathrm{~h}^{[36]}$.

\section{Biolog Data Analysis}

The final values used to represent the activity in each well were the $590 \mathrm{~nm}$ values minus the $750 \mathrm{~nm}$ values after being corrected for readings in the control well at these wavelengths. Well optical density values that were negative or under 0.06 were set to zero ${ }^{[36]}$. Average well color development (AWCD) was calculated as described by Garland and colleagues, i.e. AWCD $(590-750 \mathrm{~nm})=$ $\Sigma\left(\mathrm{C}_{590-750}\right) / 31$, where 31 represents the number of carbon sources used in Biolog EcoPlate. The final values of each well at $168 \mathrm{~h}$ were used to calculate the Shannon's diversity index $(H)$, where $H=-\Sigma(P i \ln P i), P i$ is the proportional optical density value of each well, and $P i=\mathrm{C}_{590-750} / \Sigma\left(\mathrm{C}_{590-750}\right)$. Normalized data were analyzed by principal component analysis.

\section{Results \\ RAPD Analysis}

In the present study, 3 arbitrary primers were used to amplify soil microbial DNA. The RAPD pattern generated by arbitrary primers OPO 05, 06 and 18 for 17 soil samples were shown in Figure 1 as gel photo. Three primers generated a total of 416 RAPD fragments with OPO 05, OPO 06 and OPO 18 generated 130, 142 and 144 fragments, respectively. The number of fragments scored per primer ranged from 1 to 11,5 to 11 and 3 to 12 for primer OPO 05, 06 and 18, respectively. Eight of the total fragments $(1.9 \%)$ were polymorphic. The ratio of polymorphic fragments in each primer was 3.1\% (OPO 05), 1.4\% (OPO 06) and 1.4\% (OPO 18), respectively (Table 2).

Table 2: Three primer amplified outputs to microbial community DNA from 17 soil samples.

\begin{tabular}{|l|c|c|c|c|}
\hline Primers & Amplified Fragment & $\begin{array}{c}\text { Non-polymorphic } \\
\text { Amplified fragments }\end{array}$ & Polymorphic fragments & $\begin{array}{c}\text { Ratio of polymorphic frag- } \\
\text { ments to total fragments }\end{array}$ \\
\hline OPO5 & 130 & 126 & 4 & $3.1 \%$ \\
\hline OPO6 & 142 & 140 & 2 & $1.4 \%$ \\
\hline OPO18 & 144 & 142 & 2 & $1.4 \%$ \\
\hline
\end{tabular}



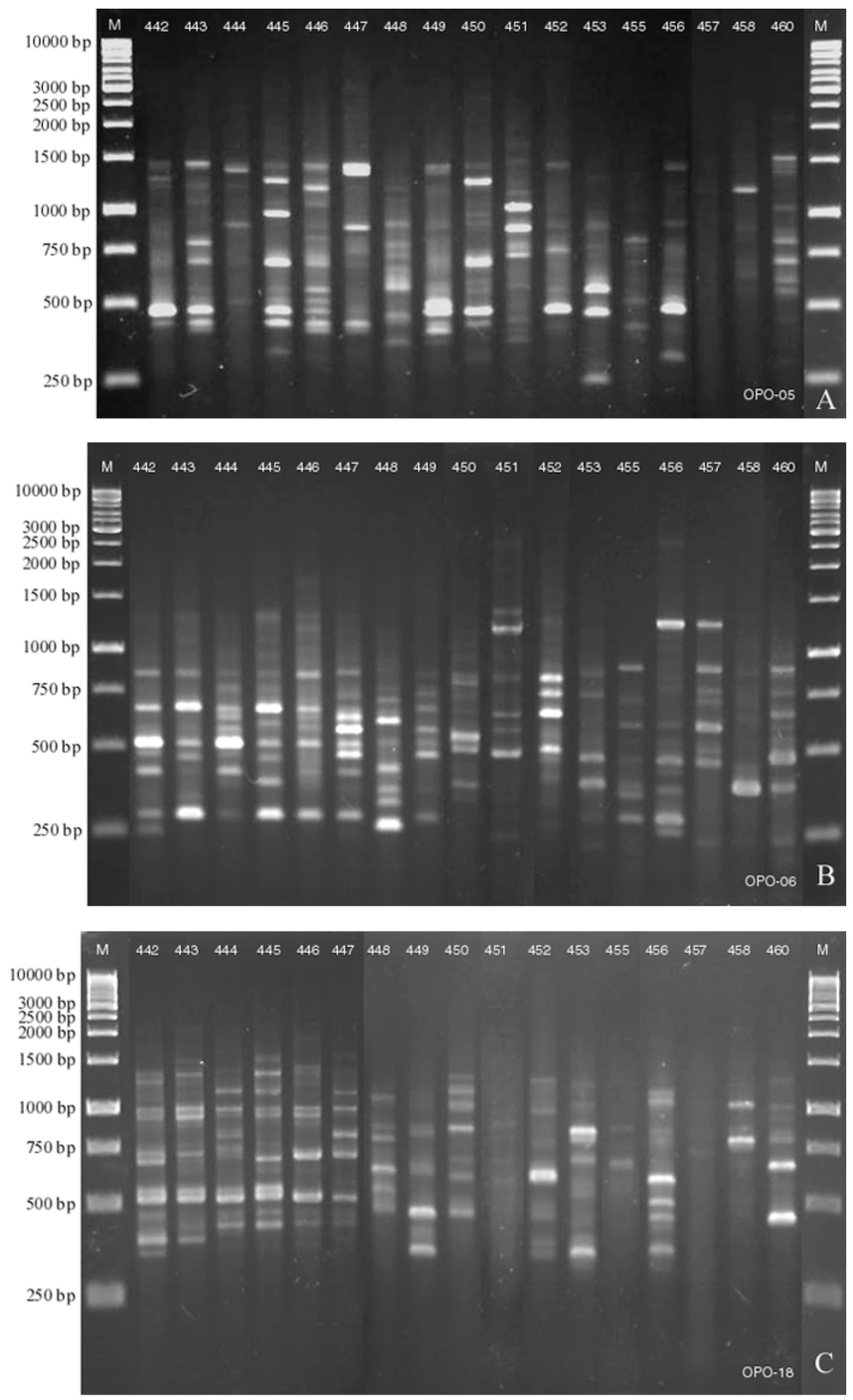

Figure 1: RAPD fingerprint for 17 soil samples for OPO 05 (A), OPO 08 (B) and OPO 18 (C). Lane "M" contain DNA molecular weight markers. The numbers indicate the soil sample number as in Table 1. 


\section{RAPD analysis - Diversity of Soil Microbial Com- munities DNA sequence}

RAPD fragment richness $(S)$ in DNA for 17 soils microbial communities in Barrientos Island are shown in Table 3. Average RAPD fragments richness for sample 445 and 446 were both 10.7, respectively, which were the highest richness among all soils from Barrientos Island. Soil sample 443, 456 and 444 were the subsequent samples with high average richness value of 10, 9.3 and 9 , respectively. Whereas soil 457 contain the lowest richness, with average only 4 RAPD fragments per primer. Three soils comprised of relatively low richness, which is 457,458 and 455 with 4, 4.3 and 5.3 RAPD fragments per primer, respectively.
The modified richness (modified $S$ ) for 17 soils showed that sample 445 had the highest value for average of modified richness (7.09); as soil 457 had the lowest value (2.44) (Table 4). By assigning a standard value of 1 for modified richness for the soil with the highest diversity (445), soils with high richness value were 445,445 and 443 with 1 , 0.95 and 0.91 , respectively. The Shannon-Weaver indices (Dsh) for microbial community at RAPD are shown in Table 5. The cumulative diversities of Shannon-Weaver indices for 445 were the highest (3.40), whereas 457 was the lowest (1.16). Coefficient of DNA sequence similarity indicated differences between soils at DNA level (Table 6). Coefficient of DNA sequence similarity was the highest (73.53) between sample 442 and 446 . The similarity coefficient between sample 447 (active Chinstrap penguin rookery) and sample 458 (seal colony rookery) was the lowest (6.07).

Table 3: Richness (S) for soil microbial community in 17 soil samples at DNA level.

\begin{tabular}{|c|c|c|c|c|c|c|c|c|c|c|c|c|c|c|c|c|c|}
\hline \multirow{2}{*}{ Primer } & \multicolumn{17}{|c|}{ Soil samples } \\
\hline & 442 & 443 & 444 & 445 & 446 & 447 & 448 & 449 & 450 & 451 & 452 & 453 & 455 & 456 & 457 & 458 & 460 \\
\hline OPO5 & 7 & 10 & 6 & 9 & 11 & 7 & 9 & 9 & 9 & 10 & 5 & 7 & 5 & 6 & 1 & 4 & 9 \\
\hline OPO6 & 7 & 9 & 9 & 11 & 11 & 9 & 9 & 8 & 8 & 6 & 9 & 6 & 7 & 11 & 8 & 5 & 9 \\
\hline OPO18 & 12 & 11 & 12 & 12 & 10 & 7 & 7 & 7 & 8 & 5 & 7 & 10 & 4 & 11 & 3 & 4 & 8 \\
\hline Total & 26 & 30 & 27 & 32 & 32 & 23 & 25 & 24 & 25 & 21 & 21 & 23 & 16 & 28 & 12 & 13 & 26 \\
\hline Average & 8.7 & 10 & 9 & 10.7 & 10.7 & 7.7 & 8.3 & 8 & 8.3 & 7 & 7 & 7.7 & 5.3 & 9.3 & 4 & 4.3 & 8.7 \\
\hline
\end{tabular}

\begin{tabular}{|c|c|c|c|c|c|c|c|c|c|c|c|c|c|c|c|c|c|}
\hline \multirow{2}{*}{ Primer } & \multicolumn{17}{|c|}{ Soil samples } \\
\hline & 442 & 443 & 444 & 445 & 446 & 447 & 448 & 449 & 450 & 451 & 452 & 453 & 455 & 456 & 457 & 458 & 460 \\
\hline OPO5 & 3.50 & 5.88 & 3.31 & 5.69 & 6.44 & 3.31 & 6.56 & 5.19 & 6.38 & 6.56 & 2.88 & 4.13 & 3.63 & 4.06 & 0.69 & 2.63 & 6.5 \\
\hline OPO6 & 3.56 & 5.81 & 4.56 & 6.88 & 7.00 & 5.00 & 6.06 & 4.44 & 4.63 & 3.56 & 6.06 & 2.94 & 4.75 & 7.69 & 5.19 & 3.13 & 5.88 \\
\hline OPO18 & 7.88 & 7.69 & 8.25 & 8.69 & 6.81 & 4.50 & 4.56 & 3.56 & 4.88 & 3.13 & 5.00 & 6.69 & 2.50 & 7.25 & 1.44 & 2.13 & 4.94 \\
\hline $\begin{array}{l}\text { Average } \\
\text { Modified } S\end{array}$ & 4.98 & 6.46 & 5.37 & 7.09 & 6.75 & 4.27 & 5.73 & 4.40 & 5.30 & 4.42 & 4.65 & 4.59 & 3.63 & 6.33 & 2.44 & 2.63 & 5.77 \\
\hline $\begin{array}{l}\text { Relative } \\
\text { Value }\end{array}$ & 0.70 & 0.91 & 0.76 & 1 & 0.95 & 0.60 & 0.81 & 0.62 & 0.75 & 0.62 & 0.66 & 0.65 & 0.51 & 0.89 & 0.34 & 0.37 & 0.81 \\
\hline
\end{tabular}

Table 5: Shannon-Weaver diversity indices (Dsh) of microbial community in 17 soil samples from random amplified polymorphic DNA (RAPD) and community level physiological profiles (CLPP) analysis.

\begin{tabular}{|l|l|l|l|l|l|l|l|l|l|l|l|l|l|l|l|l|l|}
\hline \multirow{2}{*}{ Methods } & \multicolumn{10}{|c|}{ Soil samples } \\
\cline { 2 - 22 } & $\mathbf{4 4 2}$ & $\mathbf{4 4 3}$ & $\mathbf{4 4 4}$ & $\mathbf{4 4 5}$ & $\mathbf{4 4 6}$ & $\mathbf{4 4 7}$ & $\mathbf{4 4 8}$ & $\mathbf{4 4 9}$ & $\mathbf{4 5 0}$ & $\mathbf{4 5 1}$ & $\mathbf{4 5 2}$ & $\mathbf{4 5 3}$ & $\mathbf{4 5 5}$ & $\mathbf{4 5 6}$ & $\mathbf{4 5 7}$ & $\mathbf{4 5 8}$ & $\mathbf{4 6 0}$ \\
\hline RAPD & 2.38 & 3.10 & 2.58 & 3.40 & 3.23 & 2.04 & 2.75 & 2.11 & 2.55 & 2.11 & 2.24 & 2.21 & 1.73 & 3.03 & 1.16 & 1.26 & 2.75 \\
\hline CLPP & 2.58 & 2.63 & 2.01 & 1.65 & 2.32 & 1.75 & 1.74 & 2.84 & 3.09 & 2.81 & 2.90 & 2.55 & 2.86 & 2.49 & 2.46 & 3.04 & 2.54 \\
\hline
\end{tabular}




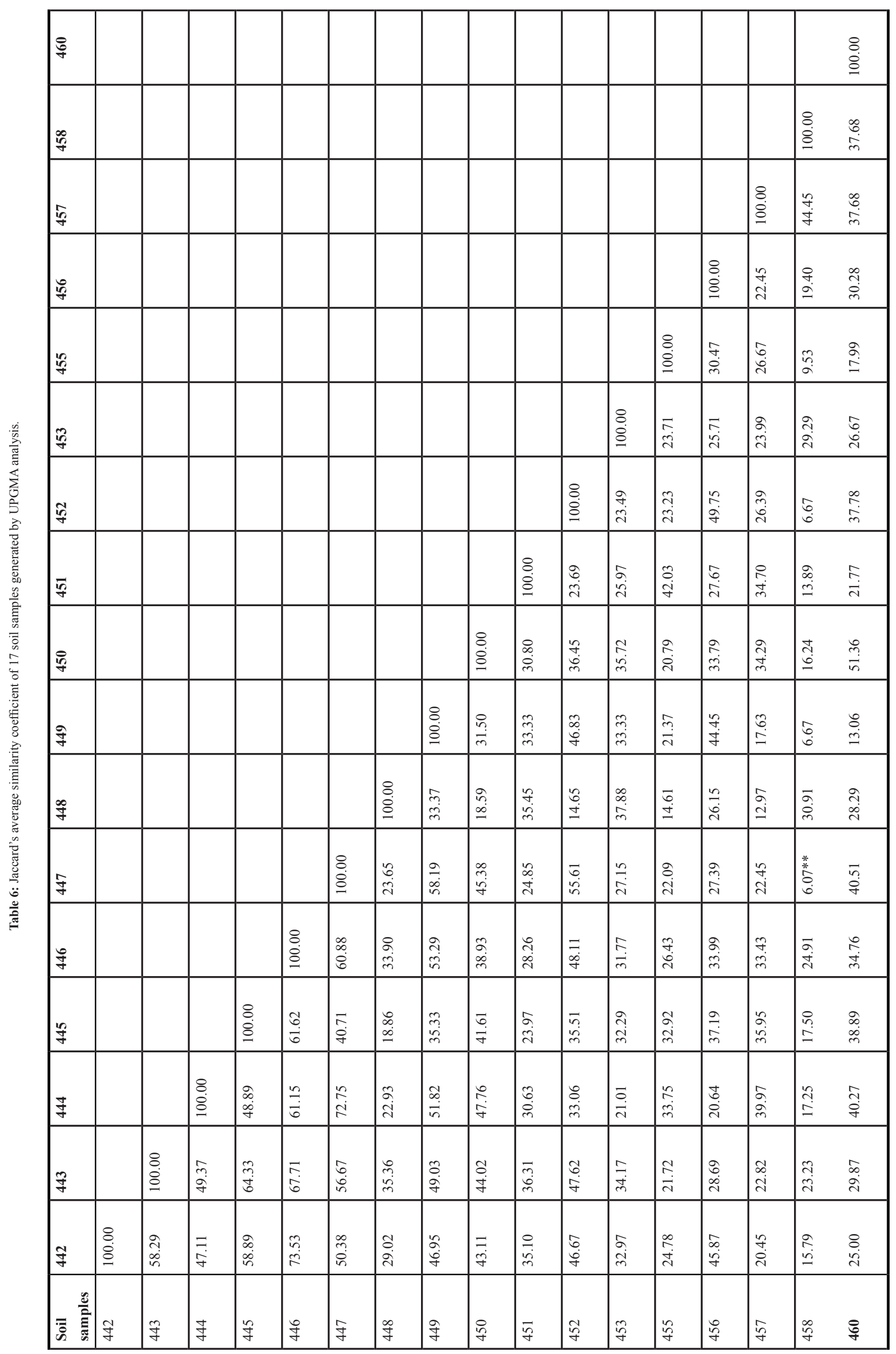




\section{RAPD analysis - UPGMA analysis of RAPD profiles}

RAPD profiles were subjected to clustering based on unweighted pair group method using arithmetic averages (UPGMA) to identify soil samples that generated patterns similar to each other. UPGMA of 17 soil samples using composite analysis of OPO 05, 06 and 18 revealed 8 clusters (Figure 2) that clade together. Within the 8 clusters produced, 5 clusters (I, III, IV, VI, VII) comprised soil samples from similar type of rookery in each respective cluster. However, some soil samples from different type of rookery were clustered together, i.e cluster II, V and VIII. Cluster I comprised of 2 abandoned penguin rookeries (452 and 456). Cluster II consisted of 1 abandoned penguin rookery (444) and 2 active Chinstrap rookeries (447 and 449). Cluster III contained 2 active Chinstrap rookeries (442 and 446) at high similarity level of $73.5 \%$ (Table 6). Cluster IV comprised 2 abandoned penguin rookeries (443 and 445) while cluster V contained 2 rookeries from abandoned penguin rookery (450) and petrel nest (460). Cluster VI comprised of 2 penguin resting rookeries (448 and 453) whereas cluster VII consisted of 2 active Gentoo rookeries (451 and 455). Lastly cluster VIII comprised of active Gentoo (457) and seal colony (460) type of rookeries.

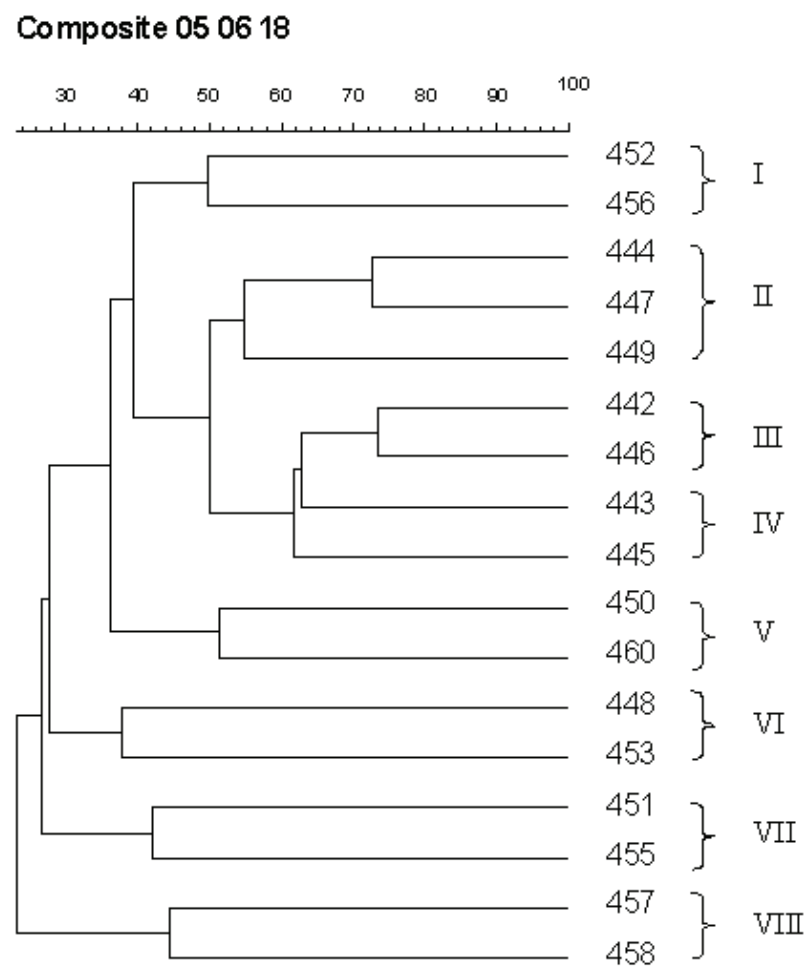

Figure 2. Dendrogram derived from RAPD composite analysis of arbitrary primer OPO 05, 06 and 18. A total of 8 clusters were formed from 17 soil samples used in this study.

\section{Biolog analysis - Average well color development}

AWCD of Biolog Ecoplates is an important index for elevated diversity of soil microbial biomass function. The values represent the changes of soil bacterial community activity in utilizing catabolic diversity in different type of rookery. The AWCD generally followed the same pattern with incubation time, but the pattern varied for different soil samples (Figure 3). In general, the AWCD value was the highest in sample 458 (active seal rookery), and lowest in sample 444 (abandoned penguin rookery). The AWCD values represent the metabolic activity of soil microbial community in using the carbon sources, thus proposed that the effect of rookery activities have influence on soil bacteria community metabolic function.

\section{Biolog analysis - Shannon's diversity}

Differences in the Shannon-Weaver index of the soil bacterial community of different rookery after incubating for $168 \mathrm{~h}$ in Biolog Ecoplate were observed (Table 5).
The Shannon indices were significantly highest in sample 450 , a soil with penguin abandoned type of rookery and soil surface covered by lots of guano. While sample 445 and 448 with low Shannon indices of 1.65 and 1.74 , respectively showed no guano at that area.

\section{Biolog analysis - Principle component analysis}

The principle component analysis was conducted to better understand differences in carbon utilization by soil microorganism. The PCA plot shows that carbon substrate utilization profiles were able to clearly separate soil samples to group according to type of rookery (Figure 4). Five significant groups were formed (A, B, C, D, E), each according to certain type of rookeries. Group $A$ and B comprised of $3(443,444,445)$ and $2(452,456)$ abandoned rookeries, respectively. Group $\mathrm{C}$ consisted of soil samples from active Chinstrap penguin rookeries (442, $446,447,448)$. Group D comprised of penguin areas $(453,457)$ while group E consisted of Gentoo penguin active rookeries $(451,455)$. 


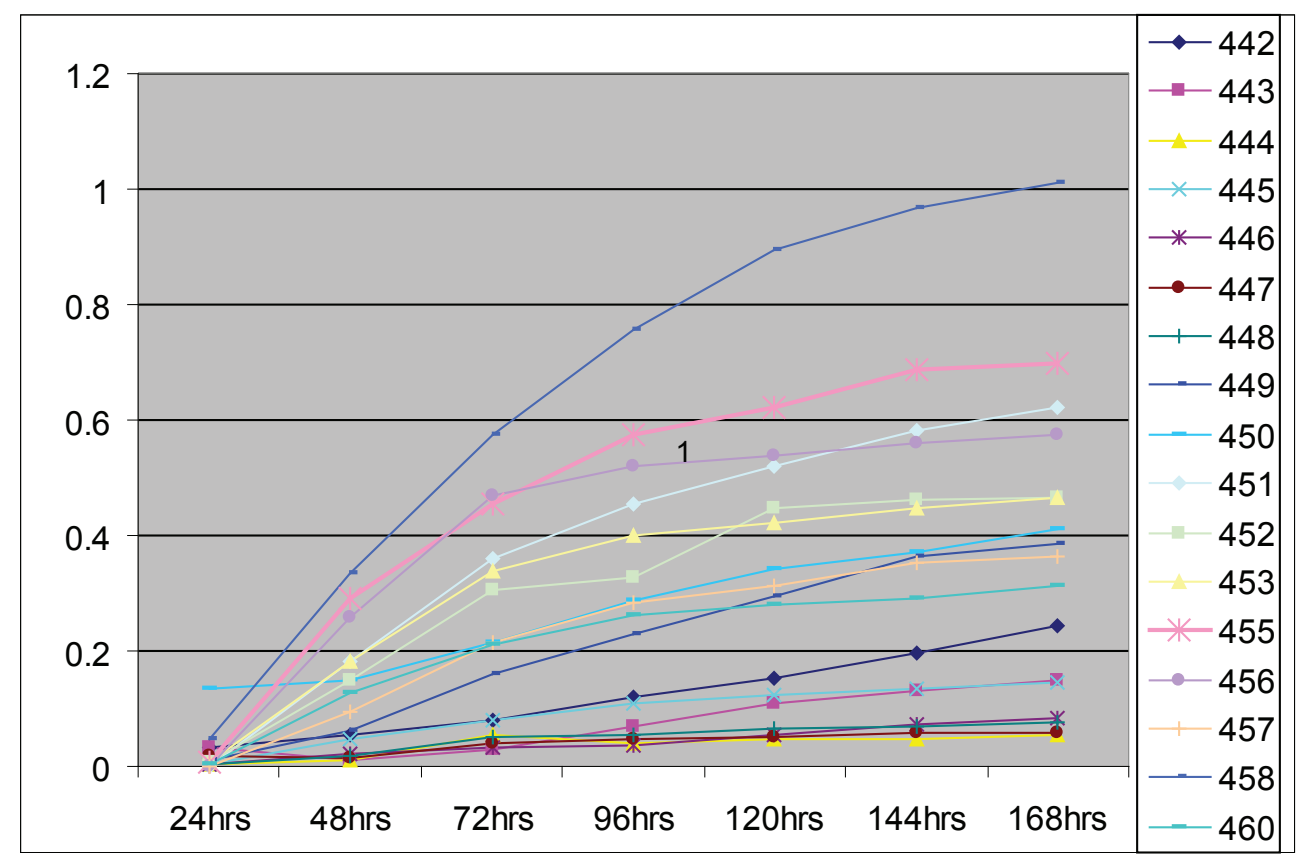

Figure 3. Difference in AWCD of soil bacterial community over time for 17 different soil samples.

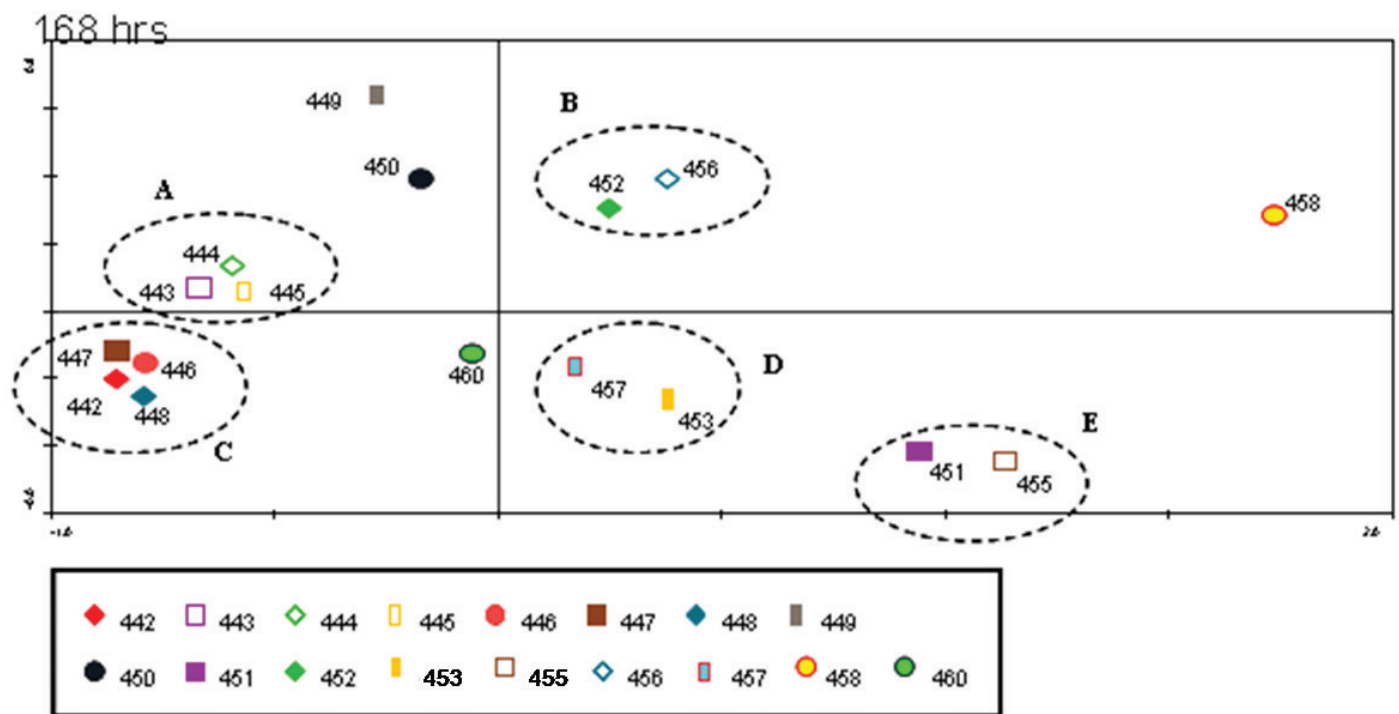

Figure 4. Principle component analysis (PCA) of Biolog EcoPlate data from different soil samples of Barrientos Island.

\section{Discussion}

The potential microbial diversity as an indicator of soil quality is impeded due to the difficulties in measuring ${ }^{[9]}$. Microbial population in soils are very large, with more than $10^{9}$ organisms per gram of soil ${ }^{[37,38]}$. It is also very diverse with more than $10^{4}$ species per gram of soil ${ }^{[39]}$. Only $1-10 \%$ of these microbes can be isolated and studied in pure culture, therefore, various microbial methods are emerging as useful tools to study microbial communities in soils ${ }^{[9,40]}$.

The difference among microbial species is fundamentally signified in their genetic diversity at DNA sequence and their metabolic function. Therefore, molecular method like RAPD and substrate utilization pattern (Biolog Ecoplate) can be used to study soil microbial community diversity ${ }^{[9]}$. PCR-based technique like the RAPD has become a popular method to assess soil microbial community as it is simple, rapid and sensitive means to identify small variations between similar genomes ${ }^{[41,42]}$. The Biolog system was initially developed for bacterial identification. Later the system has found to be useful to characterize soil microbial diversity from various different environments like soil, sediments, freshwater and seawater $^{[35]}$. The substrate utilization patterns of the Biolog system have been used to provide "fingerprints" of microbial community structure ${ }^{[43,44]}$ and also as an indication of metabolic potentials ${ }^{[45,46]}$. The multivariate analysis of the utilization pattern of different carbon substrates generated from the 96-well Biolog Ecoplates enables the classification of microbial community functional diversity. The substrate utilization patterns in this study successfully differentiated most of the soil samples according to different type of rookery. 
In this study, the RAPD analysis demonstrated that different type of rookery activities could considerably affect soil microbial communities. As $80 \%$ (4/5) of highest RAPD fragment rich samples were from abandoned penguin rookeries $(445,443,444,456)$ (Table 1 , Table 3 ). Compared to soil samples with active breeders' type of rookeries (i.e. 457, 458, 455) that exhibited average richness range from 4-5.3, soil samples of abandoned penguin rookeries $(443,444,445,450,452,456)$ showed much higher average richness with value range from 7-10.7 (Table 3). The Shannon-Weaver indices (Dsh) for the microbial community at RAPD in the 17 soils showed the average Shannon indices for abandoned penguin rookeries $(443,444,445,450,452,456)$ were significantly higher than that of rookeries with active breeders (i.e. $457,458,455)$. This observation is indeed interesting and warrant further study to understand these patterns. For Biolog Ecoplate analysis of Shannon-Weaver indices, $77 \%$ (442, 443, 446, 449, 450, 451, 452, 453, 455, 458) of soil samples with high Shannon index $(>2.3)$ (Table 5) were soil samples covered with guano, these could possibly infer that catabolic diversity of the soil bacterial community could be increased with the existence of organic manure like guano ${ }^{[1]}$. Soil samples namely 445 (3.4 for RAPD) and 450 (3.09 for CLPP) which exhibited highest Shannon index for RAPD and CLPP were both from abandoned type of rookeries. Soil samples like 443, 450 and 452 all shared high Shannon index in both RAPD and Biolog methods used. Overall the correlation of Shannon index between RAPD and Biolog is not really strong, this could be due to the variance of targeted microbes in both methods, as Biolog method only reveals fast growth bacteria activity only.

In regards to coefficient of DNA sequence similarity, results indicated the possibility of different samples colonized by different breeders caused a shift in the species composition of soil microbial communities. As for most of the soil samples colonized by similar breeders, comparatively higher coefficients of DNA sequence similarity were found, like sample 442 and 446 (both active Chinstrap rookery) shared highest similarity in DNA sequences (73.53) (Table 6).

The AWCD analysis of Biolog Ecoplates revealed changes of soil bacterial community activity in utilizing catabolic diversity in different type of rookery. From 10 soil samples with highest AWCD values, 7 were from active breeders' rookeries and only 3 were from abandoned type of rookeries. The average AWCD value for all the 9 active breeders rookeries (442, 446, 447, 449, 451, 455, $457,458,460$ ) were 0.4203 , which is significantly higher than average AWCD of 6 abandoned rookeries (443, 444, $445,450,452,456)$ with value of 0.2998 . Therefore, this suggested that the metabolic activity of soil bacteria was higher in active breeders' rookeries and lower in abandoned type of rookeries. As a result, this observation showed that the effects of rookery activities have influence on soil bacteria community metabolic function.

The cluster analysis of RAPD profiles by UPGMA showed great similarity in DNA profiles for microbial communities that shared similar type of rookery. Total $63 \%(5 / 8)$ of the clusters formed were from similar type of rookery in each respective cluster (Figure 2). These results suggest that there was a systematic change in the sequence diversity associated with different type of rookery at sampling sites. The PCA results of Ecoplate showed that carbon substrate utilization profiles were able to clearly separate most soil samples (76\%) to group according to type of rookery (Figure 4). Sample 458 and 460 , inhabited by seal and petrel respectively, both were evidently separated from the rest of the samples which were inhabited by penguins. This observation from CLPP method revealed that there is positive influence of type of rookery and soil condition towards soil microbial community diversity.

In generally, combination of molecular methods with other tools can be used to improve our understanding of the effect of different soil characteristics to soil microbial diversity. In this study, the genetic diversity of microbial populations by RAPD genetic fingerprinting and metabolic diversity using Biolog substrate utilization assays were used to investigate the effect of different type of rookery activities and characteristics on soil microbial populations. Both RAPD and CLPP method revealed the similar influence of type of rookery and soil condition towards soil microbial community diversity. The results may suggest that the change in microbial community DNA composition is accompanied with the change in microbial functional properties ${ }^{[9]}$. Nonetheless, both the methods have limitations in determining soil microbial community. The RAPD method may be affected by effects of PCR bias, like the size of random primer, sensitivity to reaction conditions and the possibility of co-migration ${ }^{[47,48]}$ Applications of random amplified polymorphic DNA (RAPD. The Biolog system assesses the metabolic diversity of culturable bacteria only. It is a system that could indicate activity of the fast growth bacteria or eutrophic bacteria only. Therefore, microorganisms like slow-growing bacteria, fungi and uncultured bacteria activity are expected to have minimal influence on the microbial metabolite profile ${ }^{[49,50]}$. So, only a part of soil microbial characteristics was discovered by the Biolog Ecoplate method.

As a conclusion, it is necessary to incorporate comprehensive approaches at diverse level, including traditional, metabolic and molecular level to understand more precisely about the changes in the diversity of microbial communities $^{[32,51]}$.

\section{Author Contributions}

The research and manuscript writing were performed by LH-L, NS-AM and VL. L-HL and Y-KC founded the research project.

\section{Conflict of Interest}

The authors declare that the research was conducted in the absence of any commercial or financial relationships that could be construed as a potential conflict of interest. 


\section{Reference}

1. Guanghua W, Junjie L, Xiaoning Q, et al. Effects of fertilization on bacterial community structure and function in a black soil of Dehui region estimated by Biolog and PCR-DGGE methods. Acta Ecologica Sinica 2008; 28(1): 220-226.

2. Zelles L. Fatty acid patterns of phospholipids and lipopolysaccharides in the characterisation of microbial communities in soil: A review. Biol Fertility Soils 1999; 29(2): 111-129.

3. Shibahara $\mathrm{F}$ and Inubushi K. Effects of organic matter application on microbial biomass and available nutrients in various types of paddy soils. Soil Sci Plant Nutr 1997; 43(1): 191-203.

4. Zhang J and Liao Z. Discussion on soil ecological fertility and its cultivation. Soil Environ Sci 2000; 9(3): 253-256.

5. Yao H, Xu J, and Huang C. Substrate utilization pattern, biomass and activity of microbial communities in a sequence of heavy metal-polluted paddy soils. Geoderma 2003; 115(1-2): 139-148.

6. Bakken LR. Separation and purification of bacteria from soil. Appl Environ Microbiol 1985; 49(6): 1482-1487.

7. Ward DM, Weller R, and Bateson MM. 16S rRNA sequences reveal numerous uncultured microorganisms in a natural community. Nature 1990; 345(6270): 63

8. Dan W, Qian Y, Zhang J-Z, et al. Bacterial community structure and diversity in a black soil as affected by long-term fertilization. Pedosphere 2008; 18(5): 582-592.

9. Yao H, Jiao X, and Wu F. Effects of continuous cucumber cropping and alternative rotations under protected cultivation on soil microbial community diversity. Plant Soil 2006; 284(1-2): 195-203.

10. Learn-Han L, Yoke-Kqueen C, Shiran M, et al. Identification of actinomycete communities in Antarctic soil from Barrientos Island using PCR-denaturing gradient gel electrophoresis. Gen Mol Res 2012; 11(1): 277-291.

11. Lee L-H, Cheah Y-K, Syakima AN, et al. Analysis of Antarctic proteobacteria by PCR fingerprinting and screening for antimicrobial secondary metabolites. Gen Mol Res 2012; 11(2): 1627-1641.

12. Letchumanan V, Chan K-G, and Lee L-H. Vibrio parahaemolyticus: A review on the pathogenesis, prevalence, and advance molecular identification techniques. Front Microbiol 2014; 5: 705.

13. Law JW-F, Ab Mutalib N-S, Chan K-G, et al. Rapid methods for the detection of foodborne bacterial pathogens: principles, applications, advantages and limitations. Front Microbiol 2015; 5: 770.

14. Law JW-F, Ab Mutalib N-S, Chan K-G, et al. An insight into the isolation, enumeration, and molecular detection of Listeria monocytogenes in food. Front Microbiol 2015; 6: 1227.

15. Khoo C-H, Cheah Y-K, Lee L-H, et al. Virulotyping of Salmonella enterica subsp. enterica isolated from indigenous vegetables and poultry meat in Malaysia using multiplex-PCR. Antonie Van Leeuwenhoek 2009; 96(4): 441

16. Learn-Han L, Yoke-Kqueen C, Shiran M, et al. Molecular characterization and antimicrobial resistance profiling of Salmonella enterica subsp. enterica isolated from 'Selom'(Oenanthe stolonifera). Int Food Res J 2009; 16(1): 191-202.

17. Lee L-H, Zainal N, Azman A-S, et al. Diversity and antimicrobial activities of actinobacteria isolated from tropical mangrove sediments in Malaysia. Sci World J 2014; 2014

18. Letchumanan V, Pusparajah P, Tan LT-H, et al. Occurrence and antibiotic resistance of Vibrio parahaemolyticus from shellfish in Selangor, Malaysia. Front Microbiol 2015; 6: 1417.

19. Ser H-L, Tan W-S, Cheng H-J, et al. Draft genome of amylolytic actinobacterium, Sinomonas humi MUSC 117T isolated from intertidal soil. Mar Genomics 2015; 24: 209-210.

20. Letchumanan V, Ser H-L, Tan W-S, et al. Genome sequence of Vibrio parahaemolyticus VP152 strain isolated from Penaeus indicus in Malaysia. Front Microbiol 2016; 7: 1410.

21. Letchumanan V, Ser H-L, Chan K-G, et al. Genome sequence of Vibrio parahaemolyticus VP103 strain isolated from shrimp in Malaysia. Front Microbiol 2016; 7: 1496

22. Ser H-L, Tan W-S, Ab Mutalib N-S, et al., Genome sequence of Streptomyces pluripotens MUSC $135 \mathrm{~T}$ exhibiting antibacterial and antioxidant activity. Mar Genomics 2015; 24: 281-283.

23. Ser H-L, Ab Mutalib N-S, Yin W-F, et al. Genome sequence of Streptomyces antioxidans MUSC 164T isolated from mangrove forest. Prog Microbes Mol Biol 2018; 1(1).

24. Ser H-L, Chan K-G, Tan W-S, et al. Complete genome of mangrovederived anti-MRSA streptomycete, Streptomyces pluripotens MUSC 135T. Prog Microbes Mol Biol 2018; 1(1).

25. Law JW-F, Tan K-X, Wong SH, et al. Taxonomic and characterization methods of Streptomyces: a review. Prog Microbes Mol Biol 2018; 1(1).

26. Lee L-H, Ab Mutalib N-S, Law JW-F, et al. Discovery on antibiotic resistance patterns of Vibrio parahaemolyticus in Selangor reveals carbapenemase producing Vibrio parahaemolyticus in marine and freshwater fish. Front Microbiol 2018; 9: 2513.

27. Law JW-F, Ser H-L, Ab Mutalib N-S, et al. Streptomyces monashensis sp. nov., a novel mangrove soil actinobacterium from East Malaysia with antioxidative potential. Sci Rep 2019; 9(1): 3056.
28. Ser H-L, Tan W-S, Yin W-F, et al. Whole genome sequence of Streptomyces humi strain MUSC 119T isolated from intertidal soil. Prog Drug Discov Biomed Sci 2019; 2(1).

29. Williams JG, Kubelik AR, Livak KJ, et al. DNA polymorphisms amplified by arbitrary primers are useful as genetic markers. Nucleic Acids Res 1990; 18(22): 6531-6535.

30. Learn-Han L, Yoke-Kqueen C, Salleh NA, et al. Analysis of Salmonella Agona and Salmonella Weltevreden in Malaysia by PCR fingerprinting and antibiotic resistance profiling. Antonie Van Leeu-wenhoek 2008; 94(3): 377.

31. Cheah Y-K, Salleh NA, Lee L-H, et al. Comparison of PCR fingerprinting techniques for the discrimination of Salmonella enterica subsp. enterica serovar Weltevreden isolated from indigenous vegetables in Malaysia. World J Microbiol Biotechnol 2008; 24(3): 327

32. Yang Y-H, Yao J, and Wang M-C. RAPD marker and substrate utilization pattern applied to study microbial community diversity in the soil affected by agricultural chemicals. J Environmental Sci Health, Part B 2004; 39(1): 125-138.

33. Zak JC, Willig MR, Moorhead DL, et al. Functional diversity of microbial communities: A quantitative approach. Soil Biol Biochem 1994; 26(9): 1101-1108.

34. Boon N, De Windt W, Verstraete W, et al. Evaluation of nested PCR-DGGE (denaturing gradient gel electrophoresis) with groupspecific 16S rRNA primers for the analysis of bacterial communities from different wastewater treatment plants. FEMS Microbiol Ecol 2002; 39(2): 101-112.

35. Garland JL and Mills AL. Classification and characterization of heterotrophic microbial communities on the basis of patterns of community-level sole-carbon-source utilization. Appl Environ Microbiol 1991; 57(8): 2351-2359.

36. Classen AT, Boyle SI, Haskins KE, et al. Community-level physiological profiles of bacteria and fungi: plate type and incubation temperature influences on contrasting soils. FEMS Microbiol Ecol 2003; 44(3): 319-328.

37. Torsvik V, Goksøyr J, and Daae FL. High diversity in DNA of soil bacteria. Appl Environ Microbiol 1990; 56(3): 782-787.

38. Torsvik V, Salte K, Sørheim R, et al. Comparison of phenotypic diversity and DNA heterogeneity in a population of soil bacteria. Appl Environ Microbiol 1990; 56(3): 776-781.

39. Klug $\mathrm{M}$ and Tiedje J. Response of microbial communities to changing environmental conditions: chemical and physiological approaches. Trends Microbial Ecol. Spanish Society for Microbiology, Barcelona 1993: 371-374.

40. Schutter M, Sandeno J, and Dick R. Seasonal, soil type, and alternative management influences on microbial communities of vegetable cropping systems. Biol Fertility Soils 2001; 34(6): 397410.

41. Rafalski J, Tingey S, and Willians J. RAPD markers-a new technology for genetic mapping and plant breeding. 1991.

42. $\mathrm{Xie} \mathrm{B}$ and $\mathrm{Xu} \mathrm{Y}$. The effect of $\mathrm{Zn}$ ions on activated sludge microbes and its DNA sequence diversity analysis. Res Environ Sci 2003; 16: 18-31.

43. Engelen B, Meinken K, Von Wintzingerode F, et al. Monitoring impact of a pesticide treatment on bacterial soil communities by metabolic and genetic fingerprinting in addition to conventional testing procedures. Appl Environ Microbiol 1998; 64(8): 2814 2821.

44. Garland JL. Patterns of potential C source utilization by rhizosphere communities. Soil Biol Biochem 1996; 28(2): 223-230.

45. Haack SK, Garchow H, Klug MJ, et al. Analysis of factors affecting the accuracy, reproducibility, and interpretation of microbial community carbon source utilization patterns. Appl Environ Microbiol 1995; 61(4): 1458-1468.

46. Wünsche L, Brüggemann L, and Babel W. Determination of substrate utilization patterns of soil microbial communities: an approach to assess population changes after hydrocarbon pollution. FEMS Microbiol Ecol 1995; 17(4): 295-305.

47. Hadrys H, Balick M, and Schierwater B. Applications of random amplified polymorphic DNA (RAPD) in molecular ecology. Mol Ecol 1992; 1(1): 55-63.

48. Yang Y-H, Yao J, Hu S, et al. Effects of agricultural chemicals on DNA sequence diversity of soil microbial community: A study with RAPD marker. Microb Ecol 2000; 39(1): 72-79.

49. Konopka A, Oliver L, and Turco Jr R. The use of carbon substrate utilization patterns in environmental and ecological microbiology. Microb Ecol 1998; 35(2): 103-115.

50. Li C, Li X, and Wang J. Effect of soybean continuous cropping on bulk and rhizosphere soil microbial community function. Acta Ecologica Sinica 2006; 26(4): 1144-1150

51. Nannipieri P, Ascher J, Ceccherini M, et al. Microbial diversity and soil functions. Eur J Soil Sci 2003; 54(4): 655-670. 